\title{
Persepsi Dewasa Awal Mengenai Kursus Pranikah
}

\author{
Radhiya Bustan ${ }^{1}$ \\ ${ }^{1}$ Program Studi Psikologi, Fakultas Psikologi dan Pendidikan, Universitas Al-Azhar Indonesia, \\ Jl.Sisingamangaraja, Jakarta 12110 \\ Email: radhiya bustan@yahoo.com
}

Abstrak - Pernikahan merupakan salah satu tugas perkembangan dewasa awal. Persiapan pernikahan yang dilakukan oleh pasangan dapat dilakukan melalui kursus pranikah. Kursus pranikah adalah pemberian bekal pemahaman dan pengetahuan tentang kehidupan rumah tangga/keluarga dalam mewujudkan keluarga sakinah, mawaddah warahmah serta mengurangi angka perselisihan, perceraian, dan kekerasan dalam rumah tangga. Penelitian ini bertujuan melihat gambaran persepsi dewasa awal tentang kursus pranikah. Penelitian ini dilakukan dengan metode kuantitatif dengan jenis penelitian survei menggunakan. Metode analisis data menggunakan analisis deskriptif yang melibatkan 30 responden. Penelitian menggunakan teknik purposive sampling dengan kriteria dewasa awal usia 18 sampai 40 tahun, masa pernikahan kurang dari 10 tahun dan sudah pernah mengikuti kursus pranikah di Kantor Urusan Agama (KUA) sebelum melangsungkan pernikahan. Hasil penelitian menunjukkan bahwa dewasa awal memiliki persepsi yang baik terhadap kursus pranikah yang ditunjukkan dengan hasil persepsi terhadap hukum pernikahan memperoleh nilai rata-rata 3,50, dimensi mengenai mekanisme dan prosedur pencatatan perkawinan serta dimensi merawat cinta kasih memperoleh nilai rata-rata 3,37. Berikutnya dimensi penanaman nilai keimanan, ketaqwaan serta akhlaqul karimah dalam keluarga memperoleh rata-rata 3,32. Dimensi terkait fikih munakahat memperoleh nilai rata-rata 3,27. Serta dimensi pengetahuan umum mengenai kursus pranikah memperoleh rata-rata 3,17. Rata-rata kedua terendah adalah terkait kesehatan reproduksi yang hanya 3,04. Dan hanya satu dimensi yang memperoleh nilai rata-rata dibawah 3 yaitu materi mengenai manajemen konflik, dengan rata-rata 2,97. Saran dari penelitian ini agar kursus pranikah dapat diikuti oleh dewasa awal dalam mempersiapkan pernikahan. Diharapkan Direktur Jenderal Bimbingan Masyarakat Islam dapat terus berkomitmen dalam menetapkan peraturan mengenai kursus pranikah dan menjadikannya sebagai persyaratan untuk melangsungkan pernikahan. Demikian juga bagi Organisasi keagamaan Islam yang telah memiliki akreditasi dari Kementerian Agama, agar terus melaksanakan pelatihan untuk penyelenggara kursus pranikah agar menghasilkan sumber daya manusia yang kompeten dalam pelaksanaan kursus tersebut. Bagi peneliti selanjutnya diharapkan untuk memaparkan keefektifan kursus pranikah guna mempersiapkan pernikahan dan mencegah terjadinya perceraian.

\section{Kata Kunci: Persepsi, Kursus Pranikah, Awal Kedewasaan}

Abstract - Marriage is one of the developmental tasks of early adulthood. Wedding preparations can be done by the pair through a premarital course. Premarital course is giving a better understanding and knowledge of the life of the household / family in realizing harmonious family, mawaddah warahmah as well as reduce the number of disputes, divorce and domestic violence. This study aims to look at the picture of early adult perceptions about premarital course. This research was conducted by a quantitative method with the type of survey research use. Methods of data analysis using descriptive analysis involving 30 respondents. Research using purposive sampling with criteria early adulthood ages 18 to 40 years, a period of less than 10 years of marriage and have completed a course of premarital at the Office of Religious Affairs (KUA) before a wedding. The results showed that mature early have a good perception of premarital courses as indicated by the results of the perception of the marriage law to obtain 
an average value of 3.50, the dimension of the mechanisms and procedures for registration of marriages as well as the dimensions of caring loving obtain an average value of 3.37 , Next dimensions planting values of faith, devotion and akhlaqul karimah in the family receives an average of 3.32. Jurisprudence related dimensions munakahat obtain an average value of 3.27. As well as the dimensions of a general knowledge of the course of premarital gained an average of 3.17. Average of the two lowest-related reproductive health is only 3.04. And only one dimension to obtain an average value below 3 that material on conflict management, with an average of 2.97. Suggestions from this study that the premarital courses can be followed by early adulthood in preparing for the wedding. Expected Director General of Islamic Community Guidance can continue to be committed in setting the rules regarding pre-marital courses and make it a requirement for a wedding. Likewise for the Islamic religious organization that has had accreditation from the Ministry of Religion, in order to continue to carry out training courses for organizers of premarital order to produce competent human resources in the implementation of the course. For further research is expected to explain the effectiveness of premarital courses to prepare for marriage and prevent divorce.

Keywords - perception, premarital courses, early adulthood

\section{PENDAHULUAN}

\section{Latar Belakang}

Dernikahan adalah ikatan sakral dalam perjalanan hidup dua individu. Pernikahan merupakan tugas perkembangan pada masa dewasa awal. Pada masa ini, dewasa awal akan memilih pasangan hidup, belajar hidup bersama dengan suami atau isteri membentuk suatu keluarga, membesarkan anak-anak, mengelola sebuah rumah tangga (Hurlock, 1994).

Pernikahan merupakan peristiwa dimana perjanjian antara dua manusia terjadi. Perjanjian suci menurut Islam sangatlah berat. Karena memerlukan tanggung jawab, komitmen, dan kasih sayang (vemale.com). Pernikahan juga mempunyai makna "perkawinan". Menurut Pasal 1 Undangundang No 1 Tahun 1974, perkawinan adalah ikatan lahir dan batin antara seorang laki-laki dan seorang perempuan sebagai suami isteri dengan tujuan membentuk keluarga (rumah tangga) bahagia yang kekal berdasarkan Ketuhanan yang Maha Esa. Eksistensi perkawinan baru terjadi apabila dua (atau lebih) orang saling memelihara pertukaran instrumental dan ekspresi secara berlanjut.

Menurut ajaran Islam hakekat perkawinan berkaitan dengan fithrah manusia yang diciptakan Tuhan berpasang-pasangan. Seperti yang ditegaskan dalam Al Qur'an surat An Nisa' ayat 1 , yang artinya:
"Hai manusia bertakwalah kepada Tuhanmu yang telah menjadikan kamu dari jiwa yang satu, dan darinya Allah menjadikan pasangannya dan dari keduanya Allah mengembangbiakkan laki-laki dan perempuan yang banyak..."

Setiap pasangan mengharapkan kehidupan pernikahan yang kekal sampai akhir hayat. Pernikahan yang baik mampu membentuk keluarga yang mempunyai fungsi agama, reproduksi, kasih sayang dan afeksi, ekonomi, perlindungan, pendidikan dan sosialisasi, serta funsi sosial budaya. Namun berbagai tantangan dan lika-liku dapat membuat bahtera pernikahan menjadi goyah dan tidak mampu melaksanakan fungsi keluarga dengan semestinya. Terutama pada masa awal pernikahan adalah tahap rentan dimana pasangan masuk ke dalam proses penyesuaian landasan kehidupan pernikahan. Apabila pasangan tidak mampu melewatinya dengan baik, maka pernikahan akan terancam perceraian.

Angka perceraian di Indonesia sangat tinggi, rata-rata secara nasional mencapai kurang lebih 200 ribu pasang atau 10\% setiap tahunnya. Perceraian banyak terjadi pada pasangan muda dengan usia pernikahan kurang dari 10 tahun. Menurut. Pusat Nasional untuk Statistik Kesehatan (2000), perceraian biasanya terjadi di usia awal pernikahan, antara usia pernikahan tahun ke lima hingga ke sepuluh. Hal ini disebabkan salah satunya karena kurang 
mampunya pasangan menyesuaikan diri dengan kehidupan pernikahan.

Pernikahan merupakan salah satu tugas dan perkembangan dewasa awal. Para psikolog perkembangan umumnya sepakat bahwa masa dewasa dimulai pada usia 18 dan 20 tahun (Upton, 2012). Masa beranjak dewasa merupakan masa transisi dari remaja menuju dewasa yang berkesinambungan, dimana rentang usia masa dewasa awal adalah antara 18 hingga 25 tahun (Santrock, 2012). Tugas perkembangan pada masa dewasa awal ini antara lain adalah menikah atau membangun suatu keluarga, mengelola rumah tangga, mendidik atau mengasuh anak (Havighurst, 2001).

Apabila pasangan muda mengalami hambatan penyesuaian diri dalam pernikahannya, maka akan menjadi konflik yang berkepanjangan dan dapat memicu perceraian. Faktor penyebab perceraian tersebut antara lain adalah masalah ekonomi, kekerasan, masalah prinsip, anak, perbedaan paham politik, agama, poligami tidak sehat, krisis akhlak, kawin paksa, alasan ekonomi, cacat biologis, tidak ada tanggung jawab (dalam rumah tangga), serta rumah tangga yang tak lagi harmonis. Untuk itu, diperlukan kesiapan dan kematangan pasangan dalam mengelola dan memelihara kehidupan perkawinan mereka. Ketahanan keluarga merupakan kemampuan memelihara kehidupan perkawinan dan menjalankan fungsi-fungsi keluarga serta kelenturan dalam menghadapi dan menyelesaikan masalah dan tantangan. Hal ini tentunya tidak terjadi dengan serta merta ketika pasangan memasuki pernikahan. Perlu adanya suatu bentuk usaha pemberian pemahaman kepada pasangan yang hendak menikah mengenai berbagai hal yang terkait dengan kehidupan pernikahan. Usaha tersebut salah satunya adalah dengan memberikan kursus pranikah yang bertujuan untuk membantu pasangan memperoleh pengetahuan mengenai pernikahan. Kursus pranikah diharapkan dapat menjadi salah satu bentuk upaya dalam mencegah perceraian. Kondisi yang menyumbang terhadap kesulitan dalam penyesuai perkawinan adalah persiapan yang kurang untuk menghadapi perkawinan, baik penyesuaian seksual, keterampilan domestic, mengasuh anak, dan manajemen keuangan (Hurlock, 1994).
Kursus pranikah adalah pemberian bekal pengetahuan, pemahaman, keterampilan dan penumbuhan kesadaran kepada remaja usia nikah tentang kehidupan rumah tangga dan keluarga. Kursus pranikah bukan semata-mata upaya prevensi terhadap kemungkinan gangguan dalam pernikahan yang akan berlangsung, namun juga untuk meningkatkan kualitas hubungan suami-istri yang baik serta memberikan kesejahteraan, rasa aman dan kebahagiaan dalam perkawinan. Dengan demikian maka akar keretakan dari hubungan dapat dihindari sedini mungkin.

Bekerjasama dalam masalah hubungan saat proses kursus pranikah berlangsung akan menjadikan kedua calon suami-istri mampu mengambil keputusan seputar pernikahan mereka, seperti, apakah akan dilakukan sesuai dengan rencana atau mungkin justru ditunda, serta berbagai kesepakatan lainnya yang telah melalui proses berpikir sehat.

Bagian terpenting dalam kursus pranikah adalah sebagai suatu kesempatan bagi kedua pasangan untuk mewaspadai adanya sikap meremehkan atas keputusan yang mereka akan ambil, menjadikan calon pasangan lebih berpikir kritis akan masa depan hubungan, kebahagian, dan kesejahteraan masing-masing.

Cinta saja tidak cukup dijadikan landasan suatu pernikahan, melainkan juga diperlukan hasil pemikiran dan juga pengambilan keputusan yang telah ditentukan secara masak yang dapat dibantu melalui proses kursus pranikah. Dewasa ini, terjadi peningkatan jumlah orang yang beranjak dewasa dan orang dewasa awal yang mengikuti pendidikan pranikah yang memberikan informasi tentang relasi (Busby \& kawan-kawan, 2007). Mungkinkah pendidikan pranikah yang diberikan dengan metode kursus tersebut dapat meningkatkan kualitas pernikahan dan mengurangi kemungkinan terjadinya perceraian? Hal ini dapat kita lihat melalui persepsi pasangan yang sudah menikah tersebut mengenai manfaat kursus pranikah yang sudah mereka peroleh dalam menjalani bahtera rumah tangga.

Hal lain yang jadi perhatian adalah pelaksanaan kursus pranikah yang belum dapat dilaksanakan secara konsisten di setiap KUA (Kantor Urusan Agama) di Jakarta. Sehingga manfaatnya pun mungkin belum dapat dirasakan secara optimal 
oleh masyarakat, terutama dalam menurunkan tingkat perceraian di Indonesia. Untuk itu, pada tahun 2013, Direktur Jenderal Bimbingan Masyarakat Islam mengeluarkan peraturan tentang pedoman penyelenggaraan kursus pra nikah (Peraturan No DJ.II/542 Tahun 2013). Peraturan ini dikeluarkan untuk meningkatkan pemahaman dan pengetahuan tentang kehidupan rumah tangga/keluarga dalam mewujudkan keluarga sakinah, mawaddah warahmah serta mengurangi angka perselisihan, perceraian, dan kekerasan dalam rumah tangga. Berdasarkan peraturan tersebut, lembaga penyelenggara kursus pra nikah diperluas pada organisasi keagamaan Islam yang telah memiliki akreditasi dari Kementerian Agama, diantaranya Badan Penasihatan, Pembinaan dan Pelestarian Perkawinan (BP4) yang merupakan mitra kerja Kementerian Agama dalam mewujudkan keluarga sakinah, mawaddah, warahmah. Sehingga tidak hanya calon pengantin saja yang dapat memperoleh kursus pranikah ini, namun dapat diberikan pada seluruh remaja atau pemuda usia nikah.

Penelitian ini akan berfokus pada bagaimana persepsi dewasa awal dalam melihat manfaat kursus pranikah yang pernah mereka peroleh dalam menjalani bahtera rumah tangga. Kursus pranikah yang dimaksud adalah yang diselenggarakan oleh Kantor Urusan Agama dalam bentuk kursus calon pengantin dan kursus pranikah yang diselenggarakan oleh organisasi-organisasi keagamaan Islam.

Melalui penelitian ini, akan dilihat gambaran persepsi dewasa awal mengenai kursus pranikah yang pernah mereka ikuti, dilihat dari aspek pendekatan teori, manfaat, tujuan, materi, dan metode pelaksanaan kursus pranikah.

\section{Masalah Penelitian}

Adapun masalah dari penelitian ini adalah mengidentifikasi gambaran persepsi dewasa awal mengenai kursus pranikah?

\section{Tujuan dan Manfaat Penelitian}

Tujuan dari penelitian ini untuk mengetahui gambaran persepsi dewasa awal mengenai kursus pranikah, ditinjau dari pengetahuan dan pemahaman mengenai hukum pernikahan, mekanisme dan prosedur pencatatan perkawinan, fikih munakahat, cara merawat cinta kasih dalam keluarga, kesehatan reproduksi, menajemen konflik dalam keluarga, penanaman nilai keimanan, ketaqwaan, serta akhlaqul karimah dalam keluarga.

Manfaat secara teoritis dari hasil penelitian ini diharapkan menjadi sumber informasi dan pengetahuan bagi calon pasangan yang akan menikah, yang sudah menikah dan lembaga yang memberikan pelayanan pendidikan/kursus pranikah dalam usaha mewujudkan keluarga sakinah mawaddah warahmah agar dapat menurunkan tingkat perceraian di Indonesia.

\section{KERANGKA TEORI}

\begin{abstract}
Persepsi
Persepsi merupakan suatu proses identifikasi dan interpretasi terhadap suatu stimulus berdasarkan informasi yang diterima. Informasi tersebut diterima melalui lima panca indera, yaitu: penglihatan, pendengaran, perasa, peraba, dan penciuman (Stuart dan Laraia, 2005).
\end{abstract}

Menurut Notoadmodjo (2005), persepsi dipengaruhi oleh pengalaman, harapan, dan pengetahuan seseorang.

Sejalan dengan itu, Sarwono (2010) menyatakan bahwa persepsi kemampuan untuk membedakan, mengelompokkan, memfokuskan informasi yang diterima melalui indra yaitu hidung, mata, telinga, lidah, dan kulit. Persepsi berlangsung saat seseorang menerima stimulus dari dunia luar yang ditangkap oleh organorgan bantunya yang kemudian masuk ke otak. Di dalamnya terjadi proses berpikir yang pada akhirnya terwujud dalam sebuah pemahaman. Pemahaman inilah yang disebut dengan persepsi.

King (2010), berpendapat bahwa persepsi adalah suatu proses mengatur dan mengartikan informasi sensoris untuk meberikan makna.

Persepsi pada penelitian ini akan berfokus pada gambaran identifikasi dan interpretasi terhadap kursus pranikah yang pernah diperoleh oleh pasangan muda yang berada pada usia dewasa awal.

\section{Kursus Pranikah}

Kursus pranikah merupakan pemberian bekal pengetahuan, pemahaman, keterampilan, dan 
penumbuhan kesadaran kepada remaja usia nikah dan calon pengantin tentang kehidupan rumahtangga dan keluarga (Modul TOT Kursus Pranikah Kementerian Agama RI, 2010).

Materi kursus pranikah yang dikeluarkan oleh Kementerian Agama RI, Direktorat Jenderal Bimbingan Masyarakat Islam berisi mengenai hukum pernikahan, mekanisme dan prosedur pencatatan perkawinan, fikih munakahat, merawat cinta kasih dalam keluarga, kesehatan reproduksi, menajemen konflik dalam keluarga, penanaman nilai keimanan, ketaqwaan, dan akhlaqul karimah dalam keluarga.

Konseling pranikah sebaiknya dimulai sekitar enam bulan hingga satu tahun sebelum pernikahan (Santrock, 2012).

Penelitian ini akan berfokus pada kursus pranikah yang dilaksanakan oleh Kantor Urusan Agama dalam bentuk kurus calon pengantin dan kursus pranikah oleh organisasiorganisasi keagamaan Islam yang telah memiliki Akreditasi dari Kementerian Agama.

\section{Materi Kursus Pranikah}

Materi kursus pranikah yang dikeluarkan oleh Kementerian Agama RI, Direktorat Jenderal Bimbingan Masyarakat Islam adalah sebagai berikut (Modul TOT Kursus Pra Nikah, 2010:

\section{Hukum Pernikahan.}

Berkaitan dengan peraturan perundangan perkawinan.

1. Pengertian dan Tujuan Perkawinan Menurut UU Nomor 1 tahun 1974 tentang Perkawinan, pernikahan atau perkawinan adalah ikatan lahir batin antara seorang pria dan seorang wanita sebagai suami istri dengan tujuan membentuk keluarga atau rumah tangga yang bahagia dan kekal berdasarkan Ketuhanan Yang Maha Esa. Adapun tujuan perkawinan menurut Islam, antara lain:

1) Membina kehidupan keluarga bahagia sejahtera

2) Hidup cinta mencintai dan kasih saying

3) Melanjutkan dan memelihara keturuan

4) Membentengi diri dari perbuatan maksiat dan menyalurkan naluri seksual secara halal; serta

5) Membina hubungan kekeluargaan dan mempererat silaturahmi antar keluarga
2. Hukum Perkawinan

Berdasarkan pasal 2 ayat (1), perkawinan adalah sah apabila dilakukan menurut hokum masing-masing agama dan kepercayaan. Serta pasal 2 ayat (2), menyatakan tiap-tiap perkawinan dicatat menurut peraturan perundangan yang berlaku. Sehingga, setiap perkawinan harus tercatat di Kantor Urusan Agama (KUA).

Hukum perkawinan didasarkan pada alasan pernikahan, yang dikelompokkan menjadi lima, yaitu:

a. Wajib, bagi seseorang yang sudah cukup umur, mampu memberi nafkah, dan khawatir tidak mampu menahan nafsu atau takut berzina.

b. Sunnah, bagi seseorang yang sudah mempunyai kemampuan member nafkah dan berkeinginan melangsungkan perkawinan, meskipun mampu menahan nafsu atau takut berzina.

c. Haram, bagi seseorang yang mempunyai maksud menyakiti hati suami/istri atau menyia-nyiakannya.

d. Mubah, bagi seseorang yang belum mampu member nafkah, sementara dirinya tidak mampu menahan nafsu dan khawatir akan berzina.

e. Makruh, bagi orang yang belum sanggup memberikan nafkah, sementara dia masih mampu menahan nafsu yang mengarah pada zina.

\section{Tata Cara Pengurusan Pernikahan}

Warganegara Indonesia yang beragama Islam yang akan melakukan pernikahan mendaftarkan diri ke Kantor Urusan Agama Kecamatan yang pelaksanaannya dilakukan oleh penghulu.

Penghulu adalah Pegawai Negeri Sipil sebagai pegawai pencatat nikah yang diberi tugas, tanggung jawab, wewenang, dan hak secara penuh oleh Menteri Agama atau pejabat yang ditunjuk sesuai peraturan perundangan yang berlaku untuk melakukan pencatatan serta pengawasan pelaksanaan nikah dan rujuk menurut agama Islam, serta membahas tatacara pendaftaran nikah serta waktu pendaftaran dan pengumum kehendak nikah agar pernikahan dapat berjalan dengan aman, tertib, dan lancar.

\section{Fikih Munakahat}

menjelaskan konsep dasar perkawinan, menjelaskan tujuan dan hikmah perkawinan, 
syarat dan rukun nikah, akad nikah dan ijab kabul, hak dan kewajiban suami isteri, menjelaskan mu'asarah bil ma'ruf, adab nikah, serta hak dan kewajiban orangtua terhadap anak.

Hikmah pernikahan bagi kedua mempelai adalah :

1) Membuat jiwa lebih tenang karena terjalinnya rasa cinta dan kasih saying yang membuat kehidupan lebih terarah.

2) Terhindar dari perbuatan maksiat, karena fitrah seksual (kebutuhan biologis) dapat tersalurkan ke jalan yang benar, halal, dan diridhai Allah.

3) Nikah merupakan jalan terbaik untuk menciptakan keturunan yang baik dan mulia sekaligus merupakan upaya menjaga kelangsungan hidup manusia sesuai dengan ajaran agama.

4) Dengan nikah dan kemudian mempunyai anak, naluri kebapakan dan naluri keibuan akan tumbuh dan berkembang saling melengkapi.

5) Nikah dapat mendorong seseorang, terutama yang laki-laki untuk bersungguh-sungguh dalam mecari rezeki yang banyak dan halal, sebab dialah yang harus bertanggung jawab terhadap istri dan anak-anaknya, baik berkaitan dengan jasamni maupun rohani mereka.

Hak dan Kewajiban Suami Istri

Setiap perjanjian menimbulkan hak dan kewajiban, begitupun dalam perkawinan. Dalam UU Perkawinan ada Bab tersendiri yang mengatur mengenai hak dan kewajiabn suami istri, yaitu berdasarkan UU No. 1 Tahun 1974, suami istri memiliki kewajiban sebagai berikut:

a) Hak dan kedudukan istri adalah seimbang dengan hak dan kedudukan suami dalam kehidupan rumah tangga dan pergaulan hidup bermasyarakat.

b) Masing-masing pihak berhak untuk melakukan perbuatan hukum.

c) Suami adalah kepala keluarga dan istri adalah ibu rumah tangga.

d) Suami istri mempunyai tempat kediaman yang tetap.

e) Suami istri wajib saling mencintai, hormat menghormati, setia member bantuan lahir, dan batin kepada pasangannya.

f) Suami wajib melindungi istrinya dan memberikan segala keperluan hidup berumah tangga sesuai dengan

kemampuannya.

g) Istri wajib mengatur urusan rumah tangga dengan sebaik-baiknya.

h) Jika suami atau istri melalaikan kewajibannya, masing-masing dapat mengajukan gugatan kepada Pengadilan Agama.

Pelaksanaan fungsi-fungsi keluarga, memahami fungsi keluarga sebagai fungsi agama, reproduksi, fungsi kasih sayang, fungsi perlindungan, fungsi pendidikan dan sosialisasi nilai, fungsi ekonomi, serta fungsi sosial budaya.

\section{Merawat Cinta Kasih dalam Keluarga}

Dalam merawat cinta kasih ada beberapa hal fundamental yang harus dijalankan diantaranya: kemitrasejajaran/kondisi harmonis antara suami isteri, saling memuji kelebihan dan menyempurnakan kekurangan, memberikan hadiah, saling memberi nasihat, saling terbuka, dll.

\section{Kesehatan Reproduksi}

Pentingnya mengetahui kondisi kesehatan reproduksi adalah:

1. Menjaga kesehatan alat reproduksi sendiri. Untuk wanita, mencuci alat kelamin dengan bersih (dari depan ke belakang). Untuk pria hampir sama, dan perlu dilakukan sunat untuk mencegah penumpukan kuman, yang menyebabkan infeksi dan gangguan kemih. Sebab, darah dan urin adalah media yang baik untuk pertumbuhan kuman.

2. Mengetahui indikator kesehatan ibu secara umum, yakni:

- Mengetahui masa subur, siklus menstruasi, dan siklus teratur/tidak teratur. Siklus normal terjadi 21-35 hari.

- Pemeriksaan kesehatan secara keseluruhan untuk menurunkan angka terjadi kelainan genetik generasi selanjutnya.

- Cek TORCH (Toksoplasma, Rubela, Citomegalovirus, Herpes Simplex).

- Imunisasi Tetanus Toksoid (TT). Penting dilakukan karena pertama kali berhubungan intim. Umumnya alat kelamin wanita mengalami luka akibat selaput darah robek. Luka ini akan menjadi jalan masuk bakteri tetanus.

- Persalinan ditolong oleh tenaga kesehatan.

- KB dalam rangka menunda dan mengatur jarak kehamilan. Kelahiran anak pertama 
dan kedua mempunyai jarak minimal tiga tahun.

\section{Manajemen Konflik dalam Keluarga \\ Macam dan faktor penyebab konflik dalam keluarga: \\ 1. Rendahnya kemampuan berkomunikasi \\ 2. Rendahnya komitmen terhadap keluarga \\ 3. Ketidakjelasan peran anggota keluarga \\ 4. Lingkungan yang kurang mendukung \\ 5. Timbulnya rasa cemburu \\ 6. Kurang tertatanya perekonomian keluarga \\ 7. Terjadinya perselingkuhan \\ 8. Adanya campur tangan pihak lain}

Tahapan Manajemen konflik:

1. Tahap Primer, merupakan tahap pencegahan terhadap terjadinya konflik keluarga. Upaya-upaya yang dapat dilakukan antara lain:

a. Mengerti terhadap pekerjaan pasangan masing-masing; berusaha membuat suami/istri merasa senang; saling menyatakan perasaan secara terbuka; menghargai pendapat/ide pasangan; menggunakan waktu luang bersama; saling memuaskan dalam kehidupan seksual.

b. Adanya komunikasi yang efektif dan dapat menjadi pendengar yang baik bagi pasangannya.

c. Jika ada masalah, komunikasi dengan pasangan agar tidak berlarut-larut.

d. Menyeimbangkan antara perasaan dan pikiran (rasional).

2. Tahap Sekunder, bagaimana cara mengatasi konflik yang sudah terjadi. Upaya-upaya yang dilakukan antara lain:

a. Mencari alternative pemecahan masalah berdasarkan sumber masalahnya.

b. Berkomunikasi secara asertif (menghargai diri sendiri dan pasangan).

c. Mencari bantuan pihak ketiga yang kompeten, seperti psikolog atau konselor perkawinan.

d. Memilih cara yang terbaik (salah satu).

e. Melaksanakan cara yang sudah dipilih dari kompromi di atas.

f. Evaluasi penyelesaian konflik.

3. Tahap Tersier setelah konflik teratasi. Pasangan berusaha untuk mempertahankan komunikasi yang efektif. Perlu kesepakatan baru agar tidak terjadi konflik yang sama di masa yang akan dating.

\section{Penanaman Nilai Keimanan, Ketaqwaan dan Akhlaqul Karimah dalam Keluarga.}

Dengan aqidah yaitu iman atau kepercayaan/keyakinan, sumbernya adalah $\mathrm{Al}$ Qur'an. Ahli ilmu jiwa mengatakan bahwa pembinaan mental dan kepribadian itu dimulai jauh sebelum dalam kandungan., yaitu sejak hubungan suami istri dilakukan dengan caracara dan dengan adab yang baik, sopan dan menurut ajaran agama serta dimulai dengan do'a diwaktu melakukan hubungan suami istri. Kedua calon ibu bapak itu dalam rumah tangga selalu rukun damai dan tetap taat menjalankan ajaran agama, maka insyaAllah nantinya akan membuahkan keturunan yang baik yang mendapat perbekalan unsur-unsur agama dalam diri anak yang akan lahir nanti. Begitu bayi lahir dari kandungan, maka sang ayah menyambutnya dengan syukur kepada Allah dan membaca pada kedua telinga anak itu kalimat adzan dan iqamat sebagaimana ajaran yang telah dusunnatkan oleh Nabi Muhammad SAW.

\section{Dewasa Awal}

Masa beranjak dewasa merupakan masa transisi dari remaja menuju dewasa yang berkesinambungan. Rentang usia masa dewasa awal antara 18 hingga 25 tahun (Santrock, 2012). Sedangkan menurut Hurlock, masa dewasa awal dimulai pada umur 18 tahun sampai kira-kira umur 40 tahun. Pendapat Hurlock ini digunakan dalam menentukan usia responden dalam penelitian ini.

Dalam tahun sejak usia dewasa secara hukum sampai usia tiga puluh tahun, kebanyakan lakilaki dan wanita berupaya menyesuaikan diri dalam kehidupan perkawinan, peran sebagai orang tua dan karir mereka (Hurlock, 1994). Menurut Levinson, memasuki dunia dewasa, orang dewasa membangun struktur kepribadian mereka yang pertama, kerap dengan mengambil dan menguji suatu pilihan karier dan dengan menikah/membentuk suatu hubungan yang stabil. Mereka bekerja dmei kesuksesan, mencari pasangan yang suportif dan/atau pembimbing, dan tidak banyak mempertanyakan hidup mereka (Upton, 2012).

Beberapa tugas perkembangan pada masa dewasa awal adalah memilih pasangan hidup, 
belajar hidup bersama dengan suami atau isteri membentuk suatu keluarga, membesarkan anak-anak, mengelola sebuah rumah tangga (Hurlock, 1994).

Sekitar tahun 1930, pernikahan yang stabil secara luas dianggap sebagai titik akhir dari perkembangan orang dewasa. Dalam kurun waktu 60 tahun terakhir, pemenuhan kebutuhan individu, baik di dalam maupun di luar pernikahan telah muncul sebagai tujuan yang menyaingi stabilitas perkawinan (Skolnick, 2007). Hambatan penyesuaian diri juga dapat memicu perceraian pada masa awal perkawianan.

\section{METODE PENELITIAN}

\section{Jenis Penelitian}

Penelitian ini dilakukan dengan metode kuantitatif dengan jenis penelitian survei. Penelitian survei merupakan penelitian yang menggunakan kuesioner sebagai instrumen penelitian. Kuesioner merupakan lembaran yang berisi beberapa pernyataan dengan struktur yang baku (Prasetyo \& Miftahul Jannah, 2005).

\section{Subyek Penelitian}

Populasi penelitian ini adalah dewasa awal yang bertempat tinggal di Jakarta. Sementara yang diambil sebagai sampel dalam penelitian ini adalah 30 orang dewasa awal usia $18-40$ tahun yang berdomisili di daerah Jakarta Selatan.

Penentuan jumlah subyek penelitian yang akan digunakan, ditentukan berdasarkan batas minimal yang dikemukakan oleh Guilford \& Fruchter (1978), yaitu tidak kurang dari 30 orang responden.

\section{Teknik Penarikan Sampel}

Teknik penarikan sampel pada penelitian ini adalah teknik penarikan sampel nonprobabilita dengan purposive sampling, dimana tidak adanya kesempatan yang sama bagi anggota populasi untuk menjadi sampel penelitian, sampel dipilih berdasarkan kriteria khusus (Prasetyo dan Jannah, 2005).

Adapunkriteria khusus untuk sampel penelitian ini adalah:
1. Pasangangan yang sudah menikah kurang dari 10 tahun, karena perceraian banyak terjadi pada pasangan muda dengan usia pernikahan kurang dari 10 tahun.

2. Berada pada masa dewasa awal usia 18 40 tahun (Hurlock), karena tugas perkembangan pada masa dewasa awal adalah memilih pasangan hidup, belajar hidup bersama dengan suami atau isteri membentuk suatu keluarga, membesarkan anak-anak, mengelola sebuah rumah tangga (Hurlock, 1994).

3. Sudah menikah dan pernah mengikuti kursus pranikah yang diselenggarakan oleh Kantor Urusan Agama dalam bentuk kurus calon pengantin dan kursus pranikah oleh organisasi-organisasi keagamaan Islam yang telah memiliki Akreditasi dari Kementerian Agama. Diharapkan melalui pengalaman yang sudah diperoleh, subjek penelitian dapat mengidentifikasi dan menginterpretasi mengenai kursus pranikah yang sudah pernah mereka ikuti.

\section{Teknik Pengolahan Data}

\section{Uji Instrumen Penelitian}

Uji instrumen dilakukan untuk mengetahui kualitas instrumen, karena instrumen yang dikatakan baik harus memenuhi dua persyaratan penting yaitu: valid dan reliabel.

\section{Validitas}

Kriteria sebuah penelitian yang dianggap sebagai penelitian ilmiah, kecermatan pengukuran sangat diperlukan.Ada dua syarat utama yang harus dipenuhi oleh alat ukur untuk memperoleh suatu pengukuran yang cermat, yaitu Validitas dan Reliabilitas.

Validitas artinya alat ukur yang digunakan dalam pengukuran, dapat digunakan untuk mengukur apa yang hendak diukur. Uji validitas dimaksudkan untuk menguji ketepatan item-item dalam kuesioner, apakah item-item yang ada mampu menggambarkan dan menjelaskan variable yang diteliti.Jadi validitas adalah seberapa jauh alat dapat mengukur hal atau subjek yang ingin diukur. Validitas diusahakan dengan pikiran logis, meminta pendapat orang yang ahli, menggunakan kelompok yang telah diketahui sifatnya, kriteria independen. Item yang digunakan dalam penelitian ini untuk selanjutnya diuji reliabilitasnya. Pengujian validitas dilakukan 
untuk mengetahui apakah suatu skala psikologi mampu menghasilkan data yang akurat sesuai dengan tujuan ukurnya. Untuk uji validitas menggunakan rumus Pearson Product Moment dengan perhitungannya menggunakan program SPSS 20.0. Adapun rumus korelasi Product Moment sebagai berikut :

$r_{x y}=\frac{n \Sigma \mathrm{xy}-(\Sigma \mathrm{x})(\Sigma \mathrm{y})}{\sqrt{\left\{\mathrm{n} \Sigma \mathrm{x}^{2}-(\Sigma \mathrm{x})^{2}\right\}\left\{\mathrm{n} \Sigma \mathrm{y}^{2}-(\Sigma \mathrm{y})^{2}\right\}}}$

Keterangan:

$\mathrm{r}_{\mathrm{xy}}$ : koefisien korelasi antara $\mathrm{x}$ dan $\mathrm{y} \mathrm{r}_{\mathrm{xy}}$

N: Jumlah Subjek

$\mathrm{x}$ : Skor item

y: Skor total

$\sum x$ : Jumlah skor items

$\sum y:$ Jumlah skor total

$\sum \mathrm{x}^{2}$ : Jumlah kuadrat skor item

$\sum y^{2}:$ Jumlah kuadrat skor total

\section{Reliabilitas}

Reliabilitas artinya memiliki sifat dapat dipercaya, yaitu apabila alat ukur digunakan berkali-kali oleh peneliti yang sama atau oleh peneliti lain tetap memberikan hasil yang sama. Jadi reliabilitas adalah seberapa jauh konsistensi alat ukur untuk dapat memberikan hasil yang sama dalam mengukur hal dan subjek yang sama.Reliabilitas mengandung 3 makna yaitu:

1. tidak berubah-ubah.

2. konsisten.

3. dapat diandalkan

Pengujian reliabilitas suatu skala dilakukan untuk melihat keterandalan atau ketetapan atau kekonsistenan suatu skala alat ukur. Pengukuran realibilitas akan menghasilkan suatu skor yang dapat dipercaya yang dihasilkan oleh faktor perbedaan yang sesungguhnya dan bukanlah ditentukan oleh faktor kesalahan (Azwar,2000). Untuk menguji besarnya realibilitas instrument penelitian, dalam penelitian ini penulis menggunakan rumus uji realibilitas dengan teknik Alpha Cronbach. Untuk perhitungannya menggunakan program SPSS 20.0.

Adapun rumus Alpha Cronbach sebagai berikut:

$\mathrm{r}_{\mathrm{i}=} \frac{\mathrm{k}}{(\mathrm{k}-1)}\left\{1-\frac{\Sigma \mathrm{S}_{\mathrm{i}}^{2}}{\mathrm{~S}_{\mathrm{t}}^{2}}\right\}$
Keterangan :

$\mathrm{r}_{\mathrm{i}}: \quad$ reliabilitas instrumen

k: $\quad$ banyak item pertanyaan

$\Sigma \mathrm{S}_{\mathrm{i}}^{2}: \quad$ jumlah variansbutir

$\mathrm{S}_{\mathrm{t}}^{2}: \quad$ jumlah varians total

\section{Metode Analisis Data}

Adapun pengolahan data dalam penelitian ini menggunakan analisis deskriptif, yaitu analisis yang menekankan pada pembahasan data-data dan subjek penelitian dengan menyajikan datadata secara sistematik dan tidak menyimpulkan hasil penelitian (Priyatno, 2008). Satistik deskriptif menggambarkan tentang ringkasan data-data penelitian seperti mean, standar deviasi, varian, modus, dan lain-lain.

Statisik deskriptif yang digunakan antara lain adalah:

a) Dispersi yang meliputi; skor maksimum, dan minimum, rentang skor (range), simpangan baku, dan varian

b) Ukuran gejala pusat, seperti; skor rata-rata (mean), harga median, modus

\section{Alat Penelitian}

Penelitian ini menggunakan alat penelitian berupa kuesioner. Kuesioner adalah alat pengumpul data yang berupa daftar pertanyaan atau pernyataan tertulis yang dijawab sesuai dengan keadaan menurut subjek. Kuesioner dapat dijawab dengan berbagai cara, antara lain, melalui wawancara tatap muka, diisi sendiri oleh subjek, atau melalui pos. Pengisian kuesioner pada penelitian ini diisi sendiri oleh subjek dan dilengkapi dengan wawancara secara langsung dan melalui telepon untuk lebih memperdalam hasil yang diperoleh.

Beberapa kelebihan kuesioner adalah sebagai berikut :

1. Nyaman digunakan karena dapat diadministrasikan kepada banyak orang dalam satu waktu.

2. Lebih ekonomis jika dibandingkan dengan wawancara mendalam.

3. Responden merasa lebih aman karena anonimitas pada kuesioner.

Kuesioner dalam penelitian ini adalah mengenai "Persepsi dewasa awal mengenai kursus pranikah". Kuesioner ini akan mengidentifikasi persepsi berdasarkan pengetahuan dan pemahaman pasangan muda mengenai hukum pernikahan, mekanisme dan prosedur pencatatan perkawinan, fikih 
munakahat, cara merawat cinta kasih dalam keluarga, kesehatan reproduksi, menajemen konflik dalam keluarga, penanaman nilai keimanan, ketaqwaan, serta akhlaqul karimah dalam keluarga yang mereka peroleh dari kursus pranikah.

Kuesioner pada penelitian ini menggunakan skala Likert dengan kisi-kisi berikut:

Tabel 1. Kisi-Kisi Penelitian Menggunakan Skala

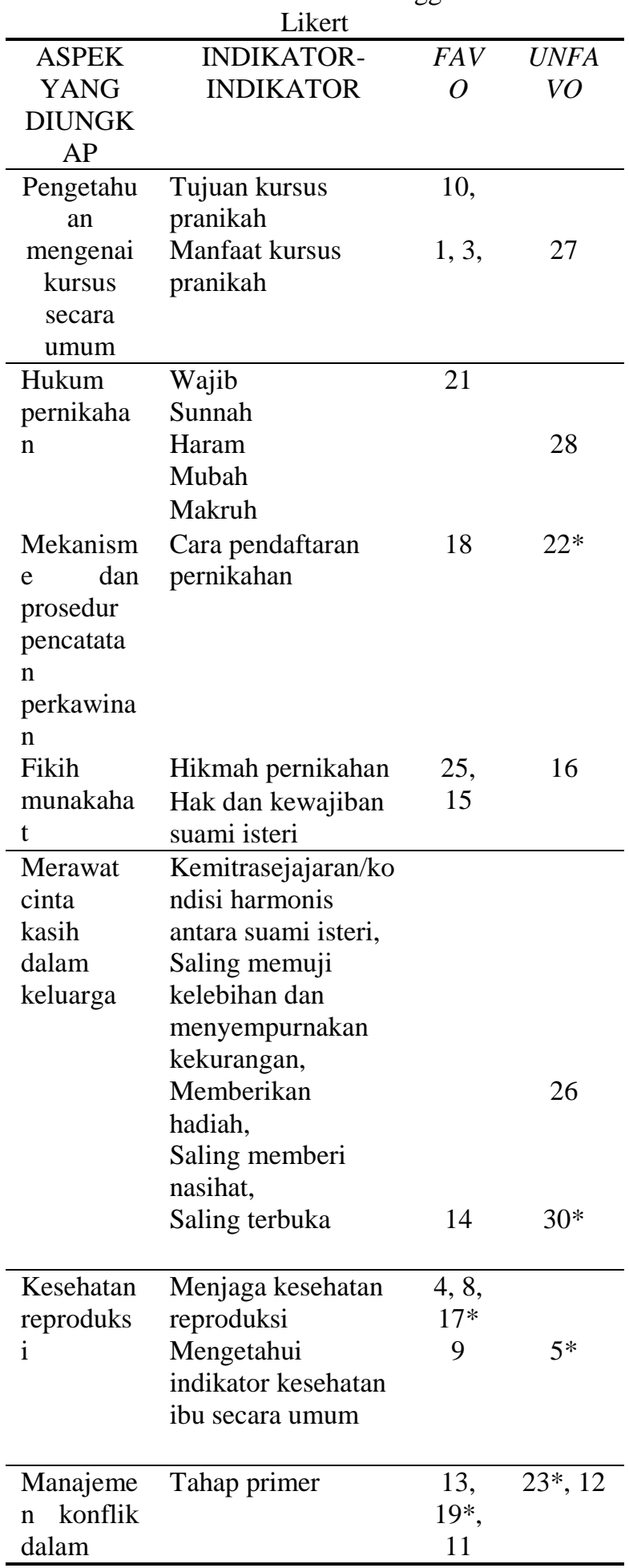

\begin{tabular}{llcc}
\hline \multicolumn{1}{c}{ ASPEK } & \multicolumn{1}{c}{ INDIKATOR- } & $F A V$ & UNFA \\
YANG & \multicolumn{1}{c}{ INDIKATOR } & $O$ & $V O$ \\
DIUNGK & & & \\
AP & & & \\
keluarga & Tahap sekunder & 2,7 & \\
& Tahap tersier & 6 & \\
Penanama & Pembinaan mental & 24, & 29 \\
n nilai & dan kepribadian & 20 & \\
keimanan, & sesuai ajaran Islam & & \\
ketaqwaa & & & \\
n serta & & & \\
akhlaqul & & \\
karimah & & \\
dalam & & \\
keluarga & & \\
\hline * Item yang tidak valid &
\end{tabular}

Kerlinger dan Lee (2000) mendefinisikan skala sebagai satu item verbal dimana individu merespon setiap item dengan cara mengekspresikan derajat persetujuan, pertidaksetujuan, atau dengan cara respon lain.

Skala Likert pada penelitian ini terdiri dari 4 alternatif jawaban untuk setiap item, yaitu mulai dari sangat setuju sampai dengan sangat tidak setuju. Kemudian peneliti menetapkan penskoran dari $1-4$. Sangat setuju mendapat skor 4, setuju mendapat skor 3, tidak setuju mendapat skor 2, dan sangat tidak setuju mendapat skor 1. Skor total didapat dengan menjumlahkan skor per item.

Dalam pengujian validitas item penelitian, terdapat 6 item yang tidak valid berdasarkan analisis statistik menggunakan SPSS 20, yaitu item $5,17,19,22,23$, dan 30. Sehingga jumlah item yang digunakan untuk analisis data adalah 24 item yang mewakili semua aspek penelitian ini.

Adapun hasil analisis reliabilitas alat ukur penelitian ini adalah sebagai berikut:

Tabel 2. Reliability Statistics

\begin{tabular}{cc}
\hline Cronbach's Alpha & N of Items \\
\hline .932 & 24 \\
\hline
\end{tabular}

Berdasarkan output SPSS di atas diperoleh hasil 0,932 yang berarti instrument yang digunakan sangat reliabel sesuai dengan kaidah Guiford yang menyatakan bahwa koefisien reliabilitas yang sangat reliabel adalah $>0,9$.

\section{Prosedur Penelitian}


Secara garis besar penelitian ini dilakukan dalam 3 tahapan, yaitu:

a. Persiapan penelitian

Hal-hal yang perlu dipersiapkan untuk penelitian ini adalah membuat alat ukur penelitian berupa kuesioner persepsi mengenai kursus pranikah. Hal lain yang perlu dipersiapkan adalah menghubungi pihak-pihak yang terkait dan dibutuhkan sebagai subjek dalam penelitian ini.

b. Pelaksanaan penelitian

Pelaksanaan penelitian ini adalah pada bulan Maret 2015 di Jakarta.

c. Pelaporan

Pada tahap ini peneliti akan melakukan pengolahan data penelitian yang sudah terkumpul. Berdasarkan hasil pengolahan dan analisis data tersebut, maka peneliti dapat membuat laporan penelitian secara lengkap dari awal sampai akhirnya menemukan jawaban masalah penelitian.

\section{HASIL DAN PEMBAHASAN}

\section{Gambaran Umum Responden Penelitian}

Subjek penelitian ini adalah dewasa awal dengan rentang usia 18-40 tahun dengan masa pernikahan kurang dari 10 tahun dan sudah pernah mengikuti kursus pranikah di Kantor Urusan Agama (KUA) sebelum melangsungkan pernikahan.

Adapun gambaran responden penelitian berdasarkan jenis kelamin adalah sebagai berikut:

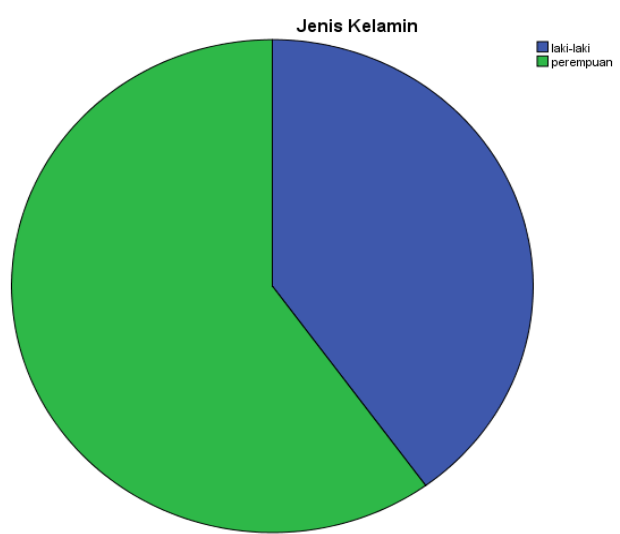

Gambar 1. Responden Berdasarkan Jenis Kelamin
Berdasarkan pie chart di atas diperoleh gambaran bahwa dalam penelitian ini terdapat 12 orang $(40 \%)$ responden laki-laki dan 18 orang $(60 \%)$ responden perempuan.

\section{Pembahasan Hasil Penelitian}

Pengolahan data dalam penelitian ini menggunakan jenis statistika deskriptif, yang merupakan metoda untuk memberikan gambaran menyeluruh tentang suatu atau beberapa kelompok dengan cara menyusun dan merangkum data kelompok/sampel.

Penelitian ini bertujuan unutk melihat persepsi dewasa awal mengenai kursus pranikah yang pernah mereka peroleh di Kantor Urusan Agama sebelum melangsungkan pernikahan, ditinjau dari delapan dimensi berikut:

1. Pengetahuan mengenai kursus secara umum, terkait manfaat dan tujuan kursus pranikah

2. Hukum pernikahan

3. Mekanisme dan prosedur pencatatan perkawinan

4. Fikih munakahat

5. Merawat cinta kasih dalam keluarga

6. Kesehatan reproduksi

7. Manajemen konflik dalam keluarga

8. Penanaman nilai keimanan, ketaqwaan serta akhlaqul karimah dalam keluarga

Berdasarkan data di lapangan diperoleh hasil analisis deskriptif masing-masing dimensi sebagai berikut:

Tabel 2. Hasil Analisis Deskriptif Masing-Masing Dimensi

\begin{tabular}{lrrrr}
\hline & N & Min & Max & Mean \\
\hline Pengetahuan Umum & 30 & 2 & 4 & 3.17 \\
Hukum Pernikahan & 30 & 3 & 4 & 3.50 \\
Mekanisme Pencatatan & 30 & 2 & 4 & 3.37 \\
Perkawinan & & & & \\
Fikih Munakahat & 30 & 3 & 4 & 3.27 \\
Merawat CintaKasih & 30 & 3 & 4 & 3.37 \\
Kesehatan Reproduksi & 30 & 2 & 4 & 3.04 \\
Manajemen Konflik & 30 & 2 & 4 & 2.97 \\
Penanaman Nilai & 30 & 3 & 4 & 3.32 \\
Valid N (listwise) & 30 & & & \\
\hline
\end{tabular}

Dari tabel output SPSS diatas, terlihat bahwa rata-rata (mean) dimensi ke 2 mengenai hukum pernikahan adalah yang paling tinggi, yaitu 3,50 dengan nilai minimum 3 dan nilai 
maksimum 4. Ini berarti dari kedelapan dimensi tersebut, dimensi terkait hukum pernikahan adalah yang paling banyak dipersepsikan secara positif oleh responden, yang berarti rata-rata responden memahami materi hukum pernikahan ini dengan baik. Hal ini juga menunjukkan bahwa pemahaman mengenai hukum pernikahan diberikan dengan baik pada kursus pranikah, sehingga responden memahami dengan baik materi ini.

Berikutnya dimensi mekanisme dan prosedur pencatatan perkawinan serta dimensi merawat cinta kasih memperoleh nilai rata-rata yang juga cukup tinggi, yaitu 3,37. Hal ini menunjukkan bahwa kedua dimensi ini juga dipersepsikan secara positif oleh responden. Responden memahami dengan baik bagaimanan mekanisme dan prosedur pencatatan perkawinan, berarti Kantor Urusan Agama melalui kursus pranikah sudah mampu mensosialisasikan materi ini dengan baik. Begitupun dengan materi mengenai bagaimana cara merawat cinta kasih dalam keluarga, materi ini juga dipahami dengan baik oleh responden penelitian.

Urutan ketiga tertinggi adalah rata-rata (mean) dari dimensi penanaman nilai keimanan, ketaqwaan serta akhlaqul karimah dalam keluarga yaitu 3,32. Hal ini menunjukkan bahwa responden penelitian ini cukup memahami mengenai penanaman nilai keimanan, ketaqwaan serta akhlaqul karimah dalam keluarga yang diberikan pada kursus pranikah yang pernah mereka ikuti. Adapun materi ini berisikan pengetahuan mengenai pembinaan mental dan kepribadian sesuai ajaran Islam.

Selanjutnya adalah dimensi fikih munakahat yang memperoleh nilai rata-rata (mean) 3, 27. Dimensi ini berisi hikmah pernikahan serta hak dan kewajiban suami isteri. Nilai mean 3, 27 tersebut menggambarkan bahwa dimensi ini juga cukup dipahami dengan baik oleh responden berdasarkan kursus pranikah yang pernah mereka peroleh di Kantor Urusan Agama ketika akan melangsungkan pernikahan.

Materi mengenai pengetahuan umum mengenai kursus pranikah secara umum memperoleh rata-rata (mean) 3,17. Materi ini berisi tujuan dan manfaat kursus pranikah secara umum, yang menunjukkan bahwa responden penelitian ini berpersepsi cukup positif terhadap tujuan dan manfaat kursus pranikah yang sudah mereka peroleh dari Kantor Urusan Agama. Nilai rata-rata ini tidak terlalu tinggi, namun masih pada kategori positif.

Berikutnya rata-rata (mean) kedua terendah adalah terkait kesehatan repproduksi yang hanya 3,04. Hal ini menunjukkan bahwa materi mengenai kesehatan reproduksi kurang dipersepsikan secara positif oleh responden. Ini dapat berarti bahwa materi tersebut kurang dipahami oleh responden atau bahkan kurang dibahas secara maksimal pada kursus pranikah yang mereka ikuti.

Rata-rata (mean) terendah adalah materi mengenai manajemen konflik, yaitu 2,97. Nilai ini menunjukkan bahwa responden cukup memahami manajemen konflik dalam keluarga, namun tidak optimal. Materi manajemen konflik dalam kursus pranikah berisi berbagai faktor penyebab konflik dalam keluarga dan tahap-tahap manajemen konflik. Materi ini dipersepsikan cukup bermanfaat bagi dewasa awal dalam mengarungi rumah tangga mereka.

Secara keseluruhan dapat diperoleh gambaran bahwa dimensi hukum pernikahan adalah dimensi yang paling dipersepsikan secara positif oleh responden penelitian ini. Hal ini berarti bahwa responden penelitian memperoleh pemahaman yang baik mengenai hukum pernikahan melalui kursus pranikah yang pernah mereka peroleh di Kantor Urusan Agama. Dimensi lainnya yang juga dinilai cukup positif adalah materi mengenai mekanisme dan prosedur pencatatan perkawinan serta bagaimana merawat cinta kasih dalam keluarga. Berdasarkan wawancara di lapangan, materi mengenai mekanisme dan prosedur pencatatan perkawinan ini umumnya diberikan pada kursus pranikah dan sudah dipahami dengan baik oleh responden. Begitu pula mengenai cara-cara merawat cinta kasih dalam keluarga secara umum juga diberikan dengan baik dalam kursus pernikahan, namun hal tersebut tidak diikuti dengan pemberian pemahaman mengenai gambaran sumbersumber konflik dalam keluarga dan tahap-tahap mengatasinya, dimana materi ini terkait dengan manajemen konflik. Hal ini terlihat dari nilai rata-rata (mean) mengenai materi manajemen konflik berada pada posisi paling rendah dibanding dimensi-dimensi lainnya yang hanya 
2,97 dengan nilai minimum 2 dan nilai maksimum 4 .

Secara umum berdasarkan analisis deskriptif diatas, pelaksanaan kurusus pranikah dipersepsikan positif dan bermanfaat bagi dewasa awal yang mengikutinya, terlihat dari hasil persepsi responden penelitian terhadap kursus pranikah yang rata-rata tergolong baik.

Hal lain yang diperoleh dari data di lapangan adalah sulitnya memperoleh responden penelitian ini dengan kriteria sudah pernah mengikuti kursus pranikah yang diberikan oleh Kantor Urusan Agama atau Organisasi Keagamaan Islam yang sudah memiliki akreditasi dari Kementerian Agama. Hampir $80 \%$ dari calon responden yang ditemui mengungkapkan bahwa mereka tidak pernah mengikuti kursus pranikah sebelum melangsungkan pernikahan, sehingga mereka tidak dapat dimasukkan sebagai responden karena tidak memenuhi kriteria.

Data tersebut menunjukkan bahwa peraturan tentang pedoman penyelenggaraan kursus pra nikah (Peraturan No DJ.II/542 Tahun 2013) oleh Direktur Jenderal Bimbingan Masyarakat Islam masih belum terlaksana dengan baik di lapangan. Peraturan ini dikeluarkan untuk meningkatkan pemahaman dan pengetahuan tentang kehidupan rumah tangga/keluarga dalam mewujudkan keluarga sakinah, mawaddah warahmah serta mengurangi angka perselisihan, perceraian, dan kekerasan dalam rumah tangga. Berdasarkan peraturan tersebut, lembaga penyelenggara kursus pra nikah diperluas pada organisasi keagamaan Islam yang telah memiliki akreditasi dari Kementerian Agama, diantaranya Badan Penasihatan, Pembinaan dan Pelestarian Perkawinan (BP4) yang merupakan mitra kerja Kementerian Agama dalam mewujudkan keluarga sakinah, mawaddah, warahmah. Sehingga diharapkan penyelenggaraan kursus pranikah ini bisa lebih maksimal dengan hadirnya berbagai lembaga lainnya selain Kantor Urusan Agama yang akan melaksanakan kursus pranikah dengan baik. Hal ini tentunya juga diharapkan dapat membantu mengurangi tingkat perceraian di Indonesia.

\section{KESIMPULAN DAN SARAN}

\section{Kesimpulan}

Berdasarkan analisis deskripstif diperoleh gambaran bahwa dimensi hukum pernikahan adalah dimensi yang paling dipersepsikan secara positif oleh responden penelitian ini. Hal ini berarti bahwa responden penelitian memperoleh pemahaman mengenai hukum pernikahan melalui kursus pranikah yang pernah mereka peroleh di Kantor Urusan Agama. Dimensi lainnya yang juga dinilai cukup positif adalah materi mengenai mekanisme dan prosedur pencatatan perkawinan serta bagaimana merawat cinta kasih dalam keluarga.

Adapun materi mengenai manajemen konflik adalah materi yang dipersepsikan kurang positif oleh responden penelitian. Hal ini berarti responden kurang memperoleh gambaran sumber-sumber konflik dalam keluarga dan tahap-tahap mengatasinya dalam mengikuti kursus pranikah, sehingga mereka kurang memahami materi tersebut.

\section{Saran}

Berdasarkan temuan data tersebut, peneliti memberikan saran sebagai berikut:

1. Dewasa awal yang akan menjadi calon pengantin diharapkan mengikuti kursus pranikah terlebih dahulu karena akan bermanfaat dalam meningkatkan pemahaman dan pengetahuan tentang kehidupan rumah tangga/keluarga untuk mewujudkan keluarga sakinah, mawaddah warahmah serta mengurangi angka perselisihan, perceraian, dan kekerasan dalam rumah tangga.

2. Diharapkan Direktur Jenderal Bimbingan Masyarakat Islam dapat terus berkomitmen dalam menetapkan peraturan mengenai kursus pranikah ini dan menjadikannya sebagai persyaratan untuk melangsungkan pernikahan.

3. Organisasi keagamaan Islam yang telah memiliki akreditasi dari Kementerian Agama, seperti Badan Penasihatan, Pembinaan dan Pelestarian Perkawinan (BP4) dan organisasi-organisasi lainnya agar terus melaksanakan pelatihan untuk penyelenggara kursus pranikah agar menghasilkan sumber daya manusia yang kompeten dalam pelaksanaan kursus tersebut. 
4. Bagi peneliti selanjutnya diharapkan untuk lebih menambah jumlah responden dengan melibatkan penyelenggara kursus pranikah sebagai evaluasi lebih mendalam mengenai kegiatan ini. Selain itu, metode pengumpulan data akan lebih kuat apabia ditambahkan wawancara mendalam dan observasi lapangan dan dapat memaparkan keefektifan kursus pranikah guna mempersiapkan pernikahan dan mencegah terjadinya perceraian.

\section{DAFTAR PUSTAKA}

[1] Guilford, J. P., and Fruchter, Benjamin. 1978.Foundamental Statistics in Psychology and Education $6^{\text {th }}$ edition. Singapore: McGraw-Hill.

[2] Hurlock, Elizabeth B.1994. Psikologi Perkembangan, Suatu Pendekatan Sepanjang Rentang Kehidupan. Jakarta: Erlangga.

[3] Kerlinger, Fred. N.2000. Asas-asas Penelitian Behavioral. Yogyakarta: Gadjah Mada University Press.

[4] King., Laura A. 2010. Psikologi Umum, Sebuah Pandangan Apresiatif. Jakarta: Salemba Humanika.
[5] Modul TOT Kursus Pra Nikah. 2010. Jakarta: Kementerian Agama RI, Direktorat Jenderal Bimbingan Masyarakat Islam, Direktorat Urusan Agama Islam dan Pembinaan Syari'ah.

[6] Sadarjoen, Sawitri Supardi. 2012. Modul Tata Laksana Couple Therapy. Jakarta: Fakultas Psikologi Universitas YARSI.

[7] Santrock, John W. 2012. Life-Span Development, Perkembangan Masa Hidup. Jakarta: Erlangga.

[8] Sarwono, Sarlito W. 2010. Pengantar Psikologi Umum. Jakarta: Raja Grafindo Persada.

[9] Peraturan Direktur Jenderal Bimbingan Masyarakat Islam Nomor DJ.II/542 Tahun 2013 tentang Pedoman Penyelenggaraan Kursus Pranikah.

[10] Prasetyo, Bambang, \& Jannah, Lina Miftahul. 2005. Teori dan Aplikasi Metode Penelitian Kuantitatif. Jakarta: PT. Raja Grafindo Persada.

[11] Priyatno, Dwi. 2008. Mandiri Belajar SPSS untuk Analisis Data dan Uji Statistik. Yogyakarta: MediaKom.

[12] Upton, Penney. 2012. Psikologi Perkembangan. Jakarta: Erlangga. 